\title{
WASTE DRUM GAS GENERATION SAMPLING PROGRAM AT ROCKY FLATS DURING FY 1989
}

\author{
D. K. Roggenthen \\ R. G. Nieweg
}

\author{
EG\&G ROCKY FLATS, INC. \\ ROCKY FLATS PLANT \\ P. O. BOX 464 \\ GOLDEN, COLORADO 80402-0464 \\ PREPARED UNDER CONTRACT DE-AC04-90DE62349 \\ FOR THE \\ ALBUQUERQUE OPERATIONS OFFICE \\ U.S. DEPARTMENT OF ENERGY
}

\section{MASTER}




\section{ACKNOWLEDGMENTS}

The authors acknowledge the assistance of W. C. Simmons, J. R. Willey, D. A. Burton, R. A. Guyer, S. D. Swanson, L. E. Watson, and the Size Reduction Crew. W. C. Simmons and J. R. Willey, Production Support Laboratory, assisted by minimizing the time required for analysis of samples. D. A. Burton, R. A. Guyer, and the Size Reduction Crew assisted in sampling the waste drums. S. D. Swanson assisted with video documentation of the waste drum sampling. 


\title{
WASTE DRUM GAS GENERATION SAMPLING PROGRAM AT ROCKY FLATS DURING FY 1989
}

\author{
D. K. Roggenthen and R. G. Nieweg
}

\begin{abstract}
Rocky Flats Plant transuranic waste drums were sampled for gas composition. Glass, metal, graphite, and solidified inorganic sludge transuranic waste forms were sampled. A vacuum system was used to sample each layer of containment inside a waste drum, including individual waste bags. $G$ values were calculated for the waste drums. $\mathrm{G}\left(\mathrm{H}_{2}\right)$ was below 0.6 and $\mathrm{G}$ (Total) was below 1.3 for all waste forms discussed in this report.
\end{abstract}

\section{INTRODUCTION}

Rocky Flats Plant (RFP) transuranic (TRU) waste will be shipped in the TRUPACT-II container to the Waste Isolation Pilot Plant. The Nuclear Regulatory Commission issued a Certificate of Compliance for TRUPACT-II in August 1989 to allow shipment of wastc. This report provides additional documentation for questions arising about gas generation of the waste material.

To answer questions about the concentration and composition of gas generation from waste material, actual gas compositions were requested to establish minimum and maximum values for hydrogen and organic solvents. Waste drums used in this study were RFP-generated waste drums stored at Idaho National Enginecring Laboratory (INEL) and retumed to RFP for examination. The waste forms are identified by item description code (IDC). The waste forms sampled contained glass, metal, graphite, and solidified inorganic sludge. Each containment layer inside the waste drum was punctured with a needle, and a gas sample was collented in gas-tight bottles and analyzed by mass spectrometry for inorganic and organic gases. The
$G$ value was calculated; the $G$ value estimates the amount of gas generated per $100 \mathrm{eV}$ of absorbed energy.

\section{EXPERIMENTAL PROCEDURE}

Gas generation sampling was performed inside each layer of containment, including individual waste bags, in RFP-generated waste drums. The TRU waste was RFP-generated waste stored at INEL and returned for examination. The TRU waste consisted of metal, glass, graphite, and solidified inorganic sludges. All sampling was performed in the airlock of the Size Reduction Facility. A vacuum pump and sampling device (Figure 1) were used to obtain the samples. The sampling device was connected to the vacuum pump approximately 24 hours before beginning waste drum sampling. The sampling device was checked for leaks and repaired before sampling.

\section{Sludge Waste Drum Sampling Procedure}

The typical solidified sludge (IDC 001 and 007) waste drum contains a rigid liner, a polyethylene (PE) round-bottom bag, and a polyvinylchloride (PVC) bag. The sludge was inside the PVC bag. Figure 2 shews a sectioned diagram of a sludge drum and the sampling points. To sample the sludge waste drum, two people wearing full-face masks and protective clothing stood inside the SRF airlock. The waste drum was moved into the airlock and the drum lid was removed. The lid of the PVC rigid liner was punctured with an awl. The awl was removed as the needle on the sampling device was lowered into the same hole. A gas sample was then taken inside the rigid liner. 


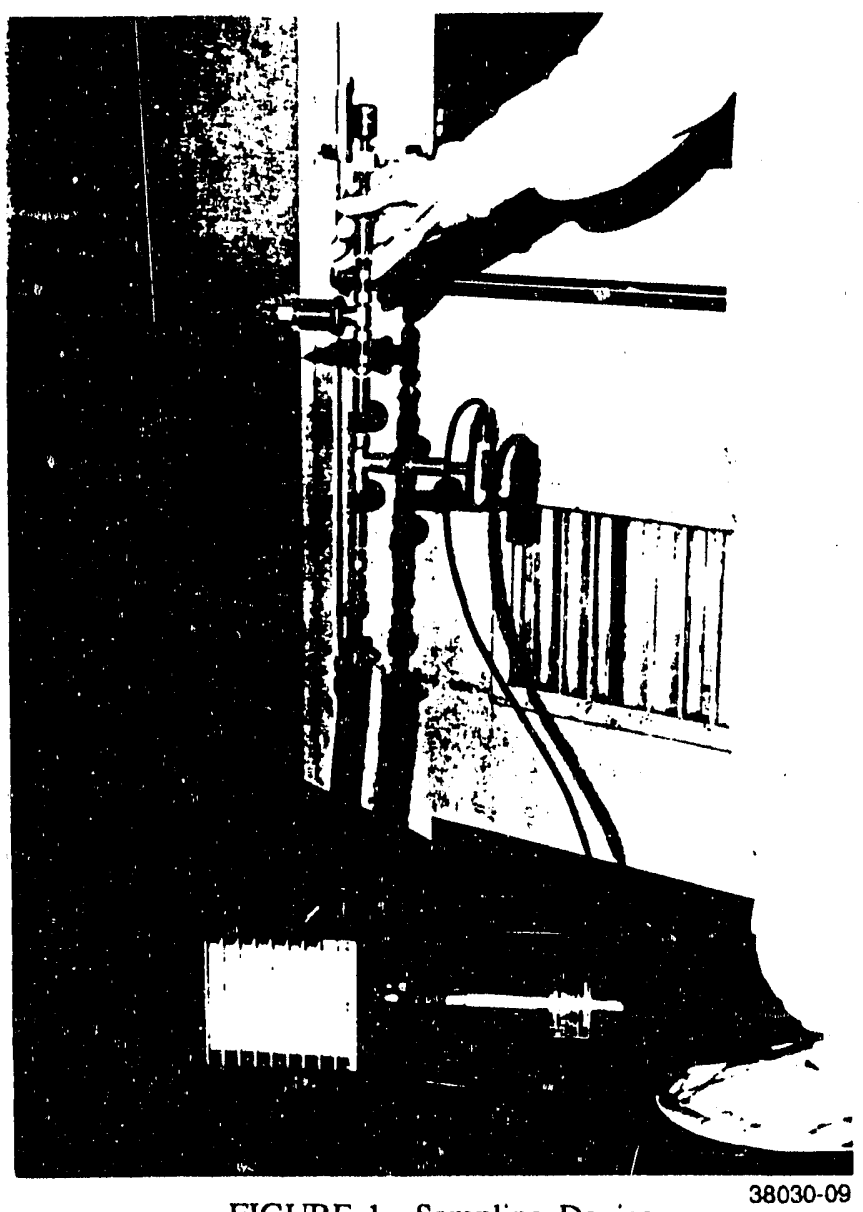

FIGURE 1. Sampling Device

Next, the rigid liner lid was removed, exposing the round-bottom PE (outer) bag. The outer bag was pulled up and isolated to allow a gas sample to be taken between the outer bag and the PVC (inner) bag. The needle on the sampling device punctured the outer bag, and a gas saniple was taken. Twoinch tape was placed over the area of the needle puncture to reseal the bag and prevent contamination of personnel. The outer and inner bag were pulled up and isolated to allow a gas sample to be taken between the inner bag and the waste material. The needle on the s:mpling device punctured both bags, and a gas sample was taken. Two-inch tape was placed over the area of the needle puncture on the outer bag. The needle hole on the inner bag was not sealed.

Normally, the rigid liner lid and drum lid would be replaced, and the drum would be sealed and returned to the waste custodian. However, plastic

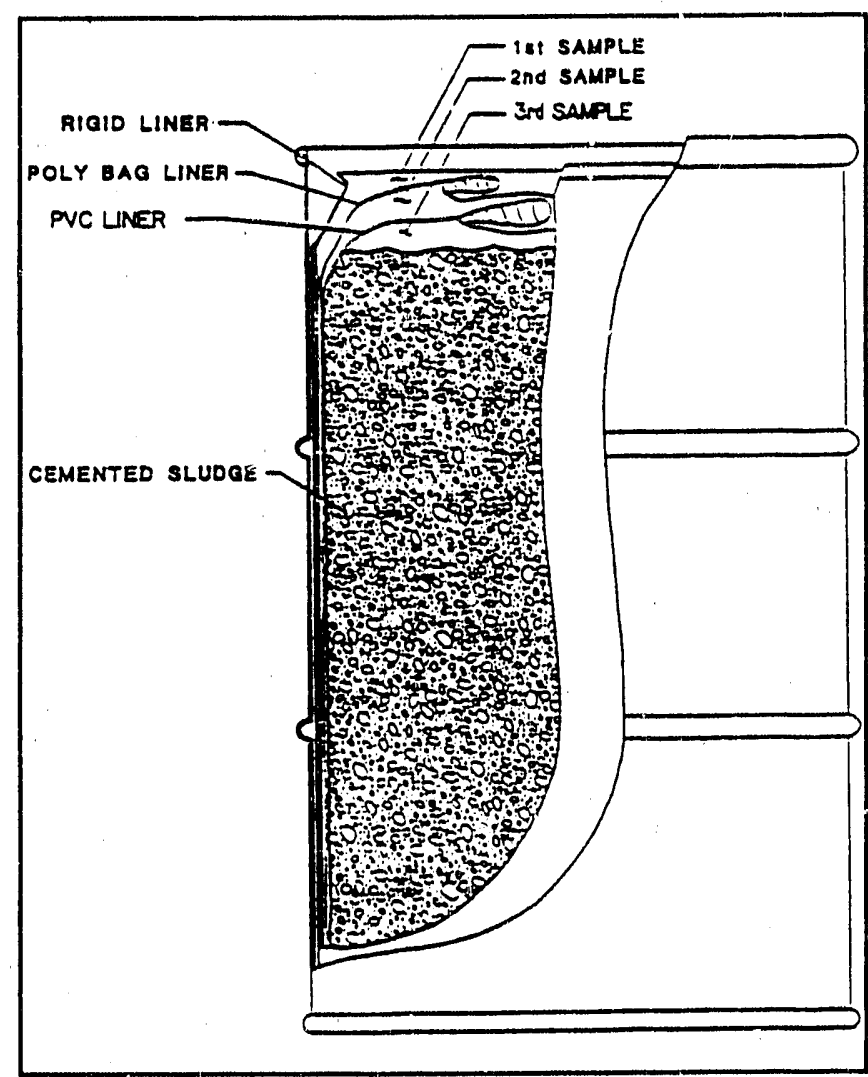

FIGURE 2. Solidified Sludge Waste Drum

bag material was also taken from three differeni areas for earh drum for hydrogen permeability measuremenis. The three areas wee: (1) top half of the polyethylene bag, (2) air-contacted polyvinylchloride, and (3) sludge contacted polyvin'yichloride. The plastic bag materia! ivas sampled inside the Size Reduction Facility. The sludge, rigid liner, and remaining bag material were repacked into different drums and then sealed and returned to the waste custodian.

The hydrogen permeability results were reported proyiously (RFP-4377). ${ }^{1}$ This report also gives results for bag material sampled from drums discussed in another report (RFP-4311). ${ }^{2}$

\section{Individual Waste Bag Sampling Procedure}

The individual waste bag sampling procedure was used for all but two code types (IDC 001 and 007). The waste drums sampled usually contained a PE 
round-bottom (outer) bag, a PVC (inner) bag, and individual packages of waste material wrapped inside small bags. For some of the waste forms, a rigid liner or cardboard liner was required before the PE round-bottom bag. For some waste forms, a PVC bag was not used. The individual waste bag sampling procedure followed the sludge waste drum sampling procedure except: (1) the outer bag was cut open after the gas sample was taken, and (2) the inner bag was cut open after the gas sample was taken. With the outer and inner bags open, individual waste bags were removed from the drum one at a time. The waste was usually contained within two plastic bags. The plastic bag's material varied, depending on origin of the waste.

The individual waste bags removed from the drum had an outer waste bag and an inner waste bag. The waste material was inside the inner waste bag. Figure 3 shows a sectioned diagram of the waste drum containing individual waste bags and the gas sampling points. A gas sample was collected between the outer waste bag and the inner waste

FIGURE 3. Sectioned Combustible Waste Drum

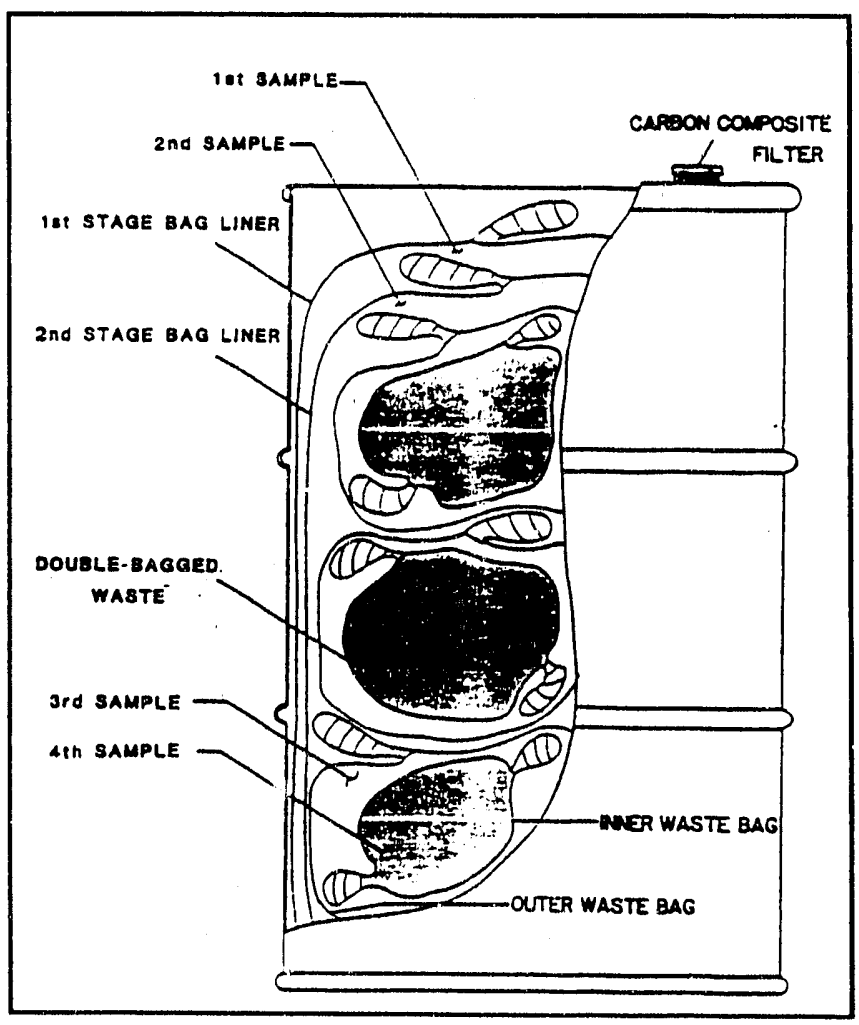

bag using the sampling device. The needle of the sampling device punctured the outer bag, and a gas sample was taken. Two-inch tape was placed over the arca of the needle puncture. A gas sample was also collected between the inner bag and the waste. Two-inch tape was placed over the area of the needle puncture on the outer bag. The needle hole in the inner bag was not sealed.

Each individual waste bag was placed into a special 55-gallon drum for assay. The special 55gallon drum was prepared by placing a cardboard box and a round cardboard piece insicie the plasticlined drum. The special 55-gallon drum was closed and assayed at the passive/active neutron (PAN) counter or the segmented gamma scanner (SGS) counter. With such small amounts of waste per drum, by positioning the individual waste bag in the center third of the drum, an assay with less reflective background was obtained. The above procedure was followed for each waste bag sampled.

\section{Gas Sampling Procedure}

A gas sample was collected inside a 10-me evacuated sampling bottle. The sampling device shown in Figure 1 consisted of a Cajon $\mathrm{VCO}^{\mathrm{R}}$ connection to a $10-\mathrm{m} \ell$ valved sampling bottle, a valved pressure gauge, a 0.5 -micron sintered metal filter, a valve before the vacuum pump, and a valved syringe needle. The sampling device was connected to the vacuum pump before sampling any waste drum and evacuated to $<30$ microns of mercury. The sampling device was evacuated to $<50$ microns of mercury between samples. The gas sample was taken using the needle of the sampling device to puncture the plastic bag.

For sampling, the valves on the sampling manifold (Figure 1) were positioned in the following order:

1. Pressure gauge valve (V2) was open

2. Vacuum valve (V3) was shut

3. Needle was inserted through the plastic bag

4. Needle valve (V4) was opened

5. Sample bottle valve (V5) was opened 
The gas sample was collected once the sample bottle was filled. The valves were positioned in the following order to replace the filled sample bottle with an empty sample bottle:

1. Needle valve (V4) was closed

2. $\quad$ Sample bottle valve (V5) was closed

3. Vacuum valve (V3) was closed

4. Filled sample bottle was removed

5. Empty sample bottle was attached

6. Sample bottle valve (V5) was opened

7. Pressure gauge valve (V2) was closed

8. Vacuum valve (V3) was opened

9. Pressure gauge valve (V2) was reopened approximately one to two minutes after opening V3.

The vacuum evacuated the sampling device and bottle to $<80$ microns of mercury. The sample bottle valve (V2) was closed. The sampling device was then prepared for the next sample

\section{Drum Assay and G Value Calculation Requirements}

To calculate the drum assay and the $G$ value for each waste drum, the following information was required. If the waste form was a sludge or did not contain individual bags of waste, the entire waste drum was assayed in the PAN or SGS counter. The individual waste bags were weighed on a platform scale. Individual waste bag dimensions of circumference and length were also taken. If the waste drum contained individual waste bags, the bags were sampled and repackaged into a 55-gallon drum for assaying at the PAN or SGS counter. Any unsampled waste bags in the original waste drum were also repackaged and assayed in the PAN or SGS counter.

The PAN drum counter gives results in passive and active mass (grams). The active mass was usually the value used in the drum assay calculations. The SGS drum counter gives results in grams of radioactive element per gram of waste.

Sludge drums were measured for the amount of free space available inside the rigid liner. The type of rigid liner was also determined. For filtered drums, the carbon composite filters have a minimum diffusion coefficient of $1.9 \times 10^{-6}$ moles/sec/mole fraction of hydrogen. The minimum diffusion coefficient for hydrocarbons was six orders of magnitude lower and considered insignificant. The minimum diffusion coefficient was determined at standard pressure and $23{ }^{\circ} \mathrm{C}$ (Reference 3). Information about the waste drums is summarized in Table 1 for sludges and Table 2 for packaged waste.

Using information from above, the drum assay was calculated. The drum assay is the total alpha activity from inside a drum or the sum of all individual waste bags inside a drum. The total alpha activity was calculated by multiplying the specific activity of each radioactive element by the weight of each radioactive element. The specific activity (curie per gram) is a constant. The specific activity values were taken from the Solid Waste Information Management System data base. For the PAN counter, the weight of each radioactive clement was calculated from the active mass value reported by the PAN counter. For the SGS counter, the weight of each radioactive element was calculated from the grams of radioactive element per gram of waste multiplied by the weight of the waste. The active mass value was assumed to be only plutonium unless an analysis of the waste form or the origin of the waste gave additional information on amcricium or uranium content.

The waste drum void volume was also calculated. The total drum void volume includes:

- Space between the rigid liner and the 55gallon drum

- Inside the rigid liner, the space above the sludge or outside of the individual waste bags

- Void space inside the individual waste bags.

RFP specifications were used to obtain dimensional information for the rigid liners and the 55-gallon drum. Knowing the type of rigid liner (I, II, or III), the void space between the inside of the 55gallon drum and the outside of the rigid liner was 
RFP-4383

TABLE 2. Packaged Wasie Gas Sample

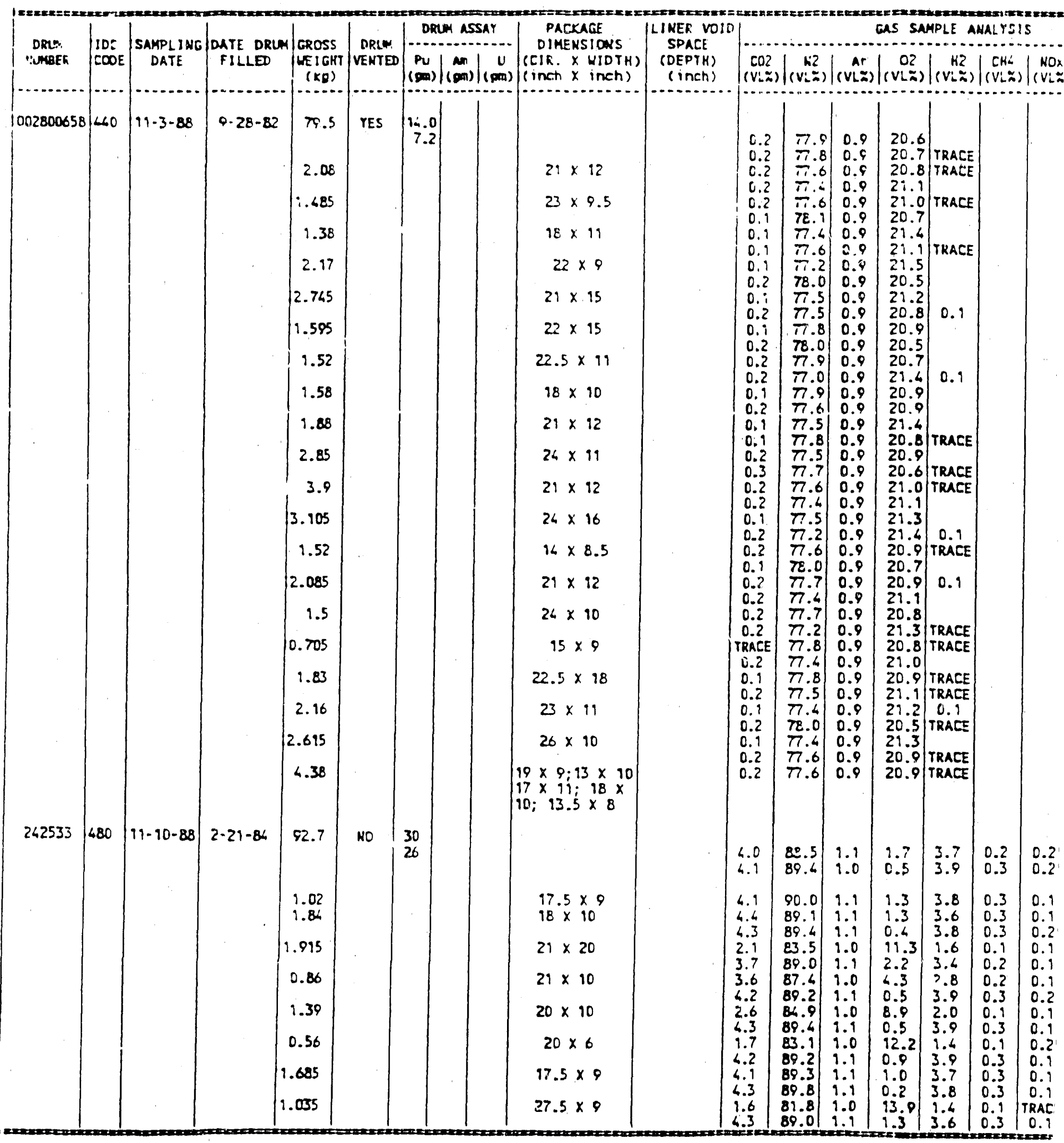


BLE 2. Packaged Waste Gas Sample

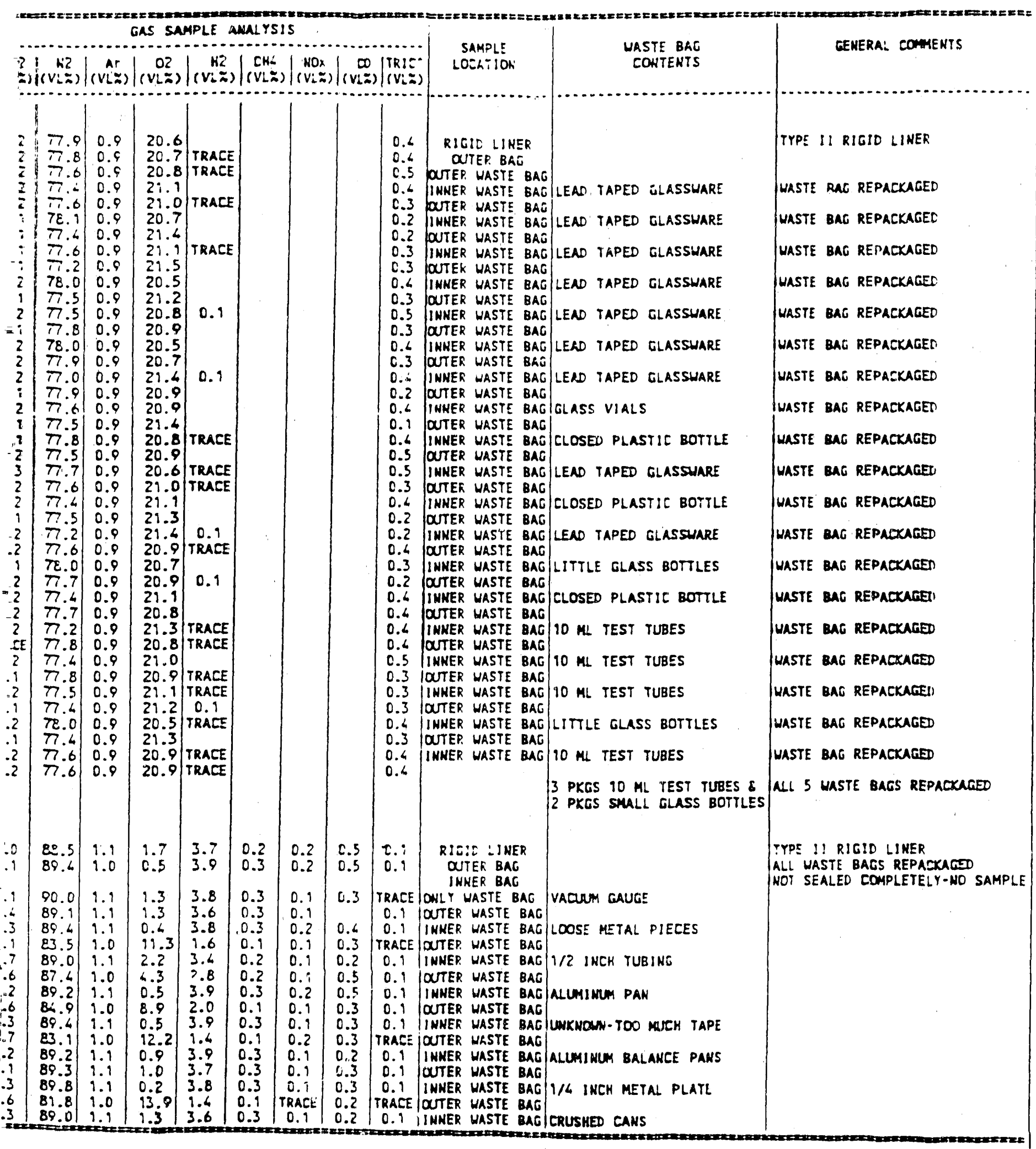


TABLE 1. Solidificd Sludge Wastc Gas Sampling
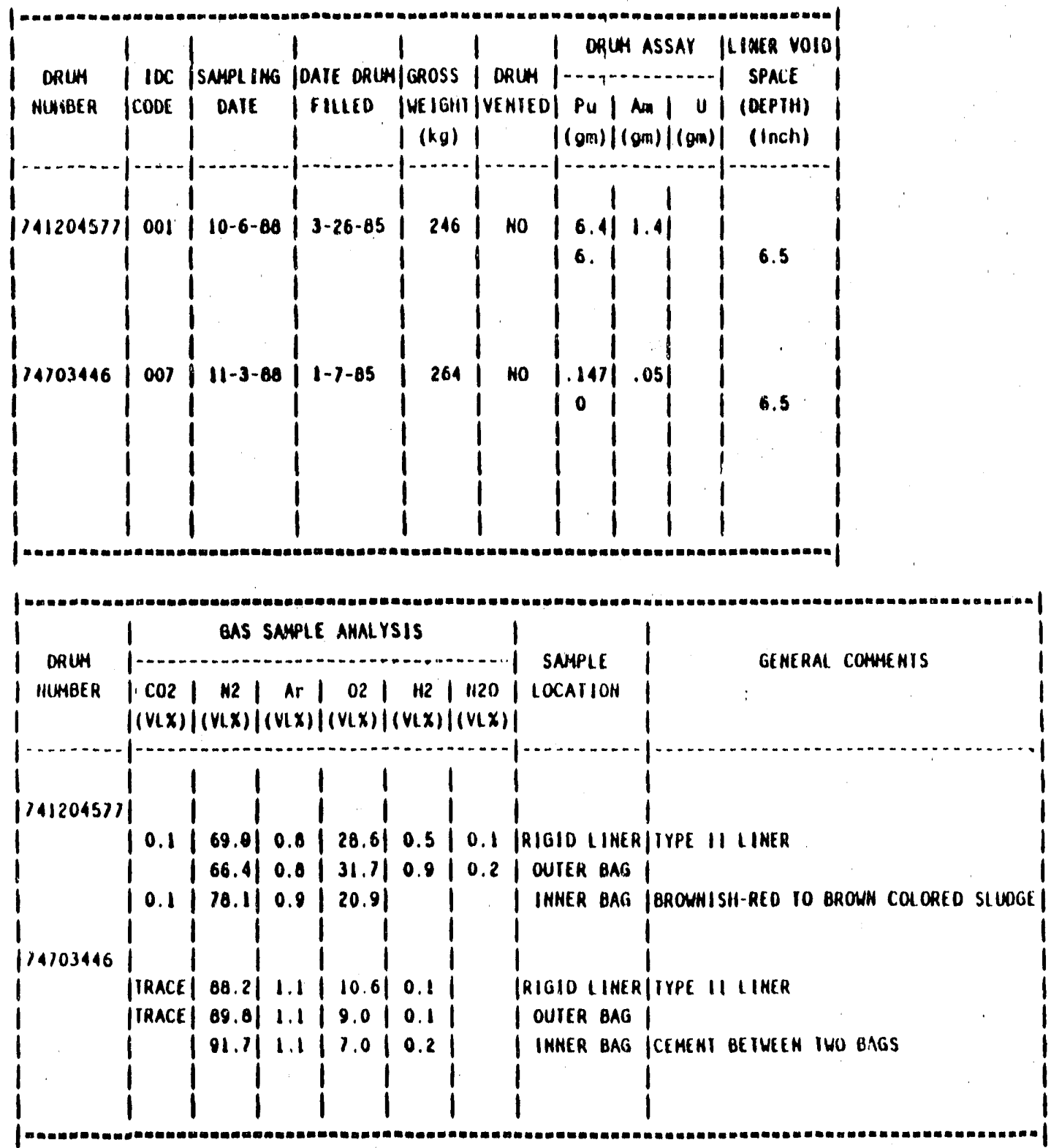


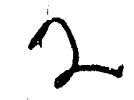

TABLE 2. Packaged Waste (ias Sample Con

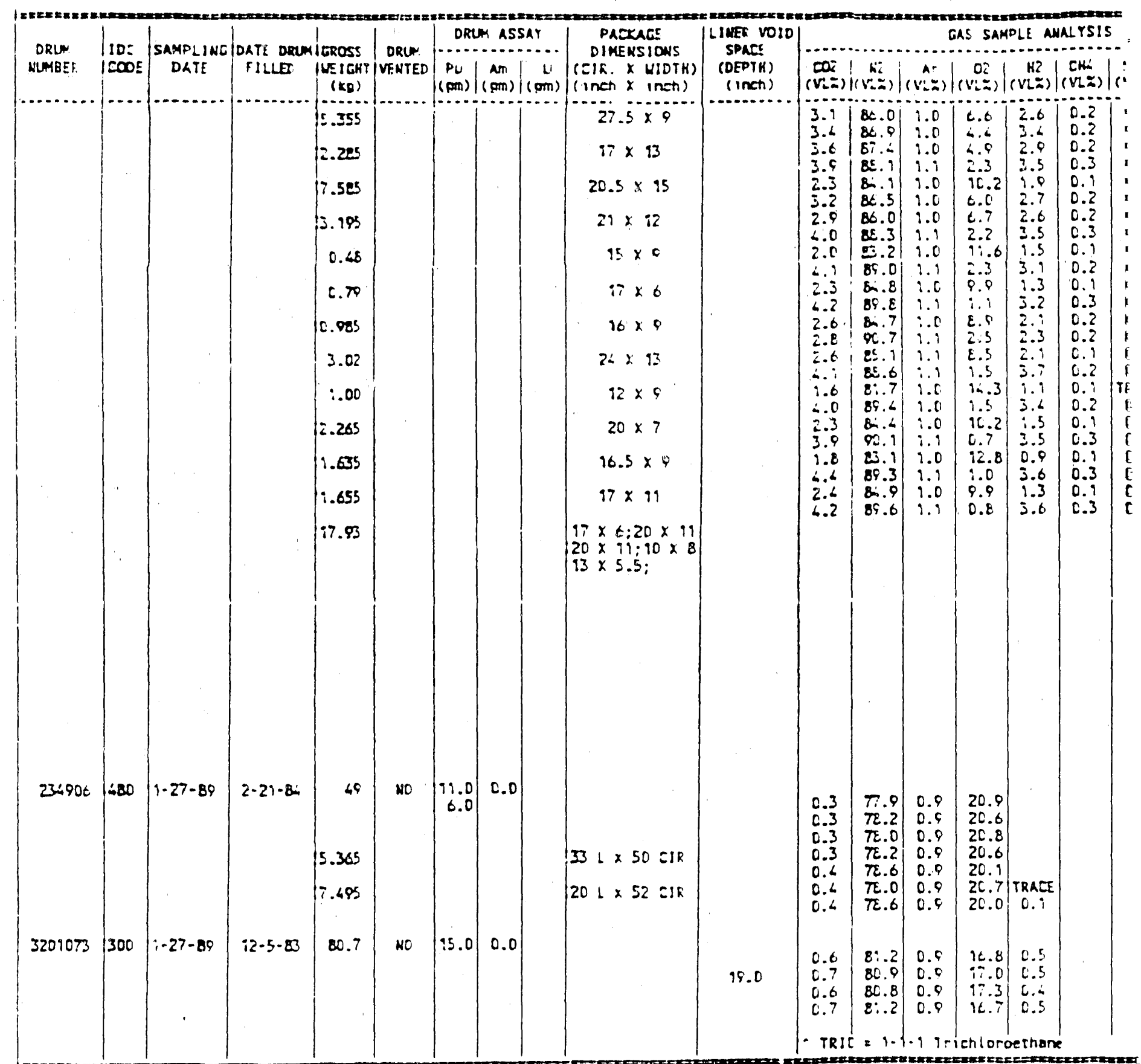


BLE 2. Packaged Waste Gas Sample Concluded

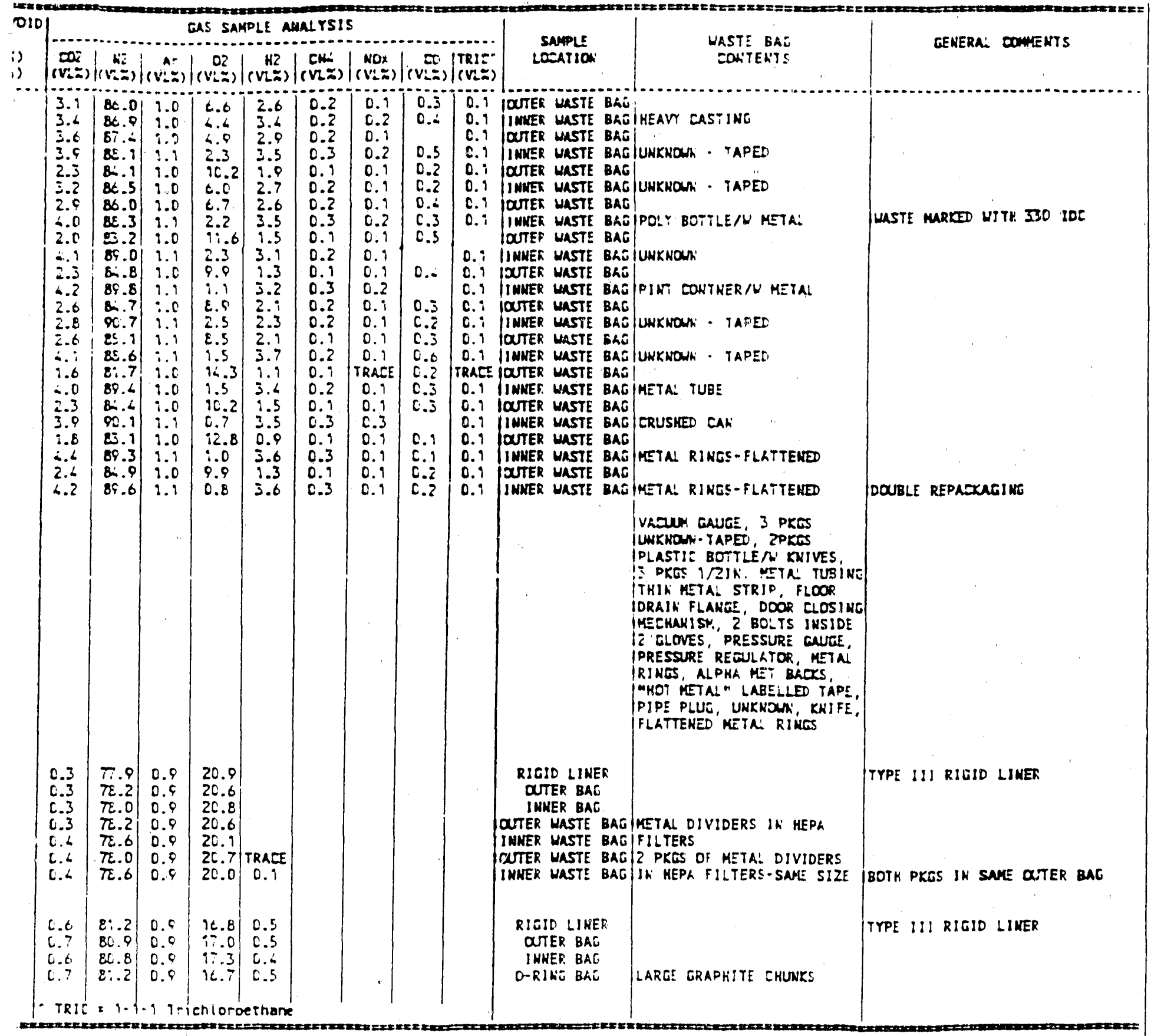


calculated. The three types of rigid liners have approximately the same outside volume, but the lid closure method varied. The inside dimensions of each rigid liner lype was obtained for purposes of calculating the void space outside the individual waste bags or above the sludge. When individual waste bags were combined into one drum for assay, the package dimension was used and totaled.

The solidified sludge waste was assumed to contain no void space. The void space for the individual waste bags was determined by sublateting the volume of the individual waste bag from the volume of waste. Individual waste bags were assumed to be right circular cylinders for volume calculations. The volume of waste was determines dividing density of the waste into the weight of an individual package or the net weight of the drum. A density was calculated for lead-taped glassware assuming the lead tape was $25 \%$ by weight. A density was also calculated for metal objects inside paper or plastic containers by assuming a weight for the container from previous measurements.

The $G$ value was calculated from the above information. G values are obtained by dividing the amount of gas generated per $100 \mathrm{cV}$ of absorbed encrgy. All calculations used standard pressure and room temperature $\left(23^{\circ} \mathrm{C}, 74{ }^{\circ} \mathrm{F}\right)$. Moles of glas gencrated were calculated from the ideal gas law based on void volume of the drum, diffusion rate of hydrogen from filtered drums, and analytical results. The moles of gas were calculated for hydrogen, carbon dioxide, and the total of all nonchlorinated compounds except nitrogen, argon, and oxygen. Except for individual waste bagss the highest total analytical results were used. Changes in oxygen concentration were not accounted for in these calculations. Absorbed energy is calculated Irom the total alpha activity calculations and the length of time since the drum had been scaled. G values for each drum were calculated from:

$$
\begin{aligned}
\mathrm{G}= & \frac{\text { moles gas } \times\left(6.02 \times 10^{23} \mathrm{molecules} / \mathrm{mole}\right)}{\mid(\text { curic Pu }) \times\left(5.23 \times 10^{4} 1(0) \mathrm{cV} / \text { dist }\right)} \\
& +(\text { curic } \mathrm{Am}) \times\left(5.64 \times 10^{4} 1(0) \mathrm{cV} / \text { dist }\right) \mid \\
& \times(\text { days drum scalcd }) \\
& \times\left(3.7 \times 10^{10} \mathrm{dist} / \mathrm{s}-\mathrm{Ci}\right) \\
& \times\left(8.64 \times 10^{4} \mathrm{~s} / \text { day }\right)
\end{aligned}
$$

\section{RESULTS AND DISCUSSION}

Six drums of waste were sampled for gas generation composition. They included one drum each of glass: (ID) 44() ), graphite (IDC 3(0)), and two drums each of metal (IDC 44(0) and inorganic solidified sludge (IDC (K)1 and (X)7). (i values were nol calculated for a graphite drum because of incomplete assay information.

(i value limits have been set for the materials being shipled inside TRIIPAC"T-II. The upper boundin!? ( $i$ values for llammable gas are 3.1 and 4.1 for the "TRUPAC"T-II." The Hammable gets (; value includes hydrogen, methane, and ellane. The maximum (i f flam (fals) calculated wals 3.1 for solid organic mallerials packaged in cardhoard and plistic. Malterials with a calculated ( (Flam (ias) greater than 4.1 are not allowed in quantitics gereater than 1 wi \% for TRUPACT-II shippable walste.

The $\mathrm{G}(\mathrm{H}$,$) and (i(Tolal) values for the inorganic$ solidified sludge ranged from $0 .(x) 1$ to $(0 .(x) 2$ and 0.001 10) ().(0)2. respectively. The $\mathrm{G}\left(\mathrm{H}_{2}\right)$ and G(Total) values for the metal, glass, and graphite waste drums ranged from 0.036 to 0.553 and 0.181 (0) 1.289), respectively. The (i value would not prevent shipment of any of these drums ceven though most were not vented. All calleu'ated values for the waste drums are shown in Tible 3. The inorganic solidified sludge ( $\mathrm{f}$ values compare favorably (o) previously reported values $(\mathrm{i}(\mathrm{H}$,$) from$ 0.005 to 0.019 and (s(Total) from 0.0006 to (1).0.20."

Possible assumptions that could introduce some crror into the ( $i$ value calculation are:

- All gases remanned insde a non liflered scalcd drum with a semi-permeable pasiket.

- Gas composition remained the same from the day the drum was closed until sampled.

- Individual wasto bags were accumuiating in the drum before closing.

- All the radiologic decay on the waste inside individual waste bags contacted the plastic matcrial. 
RFP-4383

TABLE 3. Waste Drum Gas Sampling Results

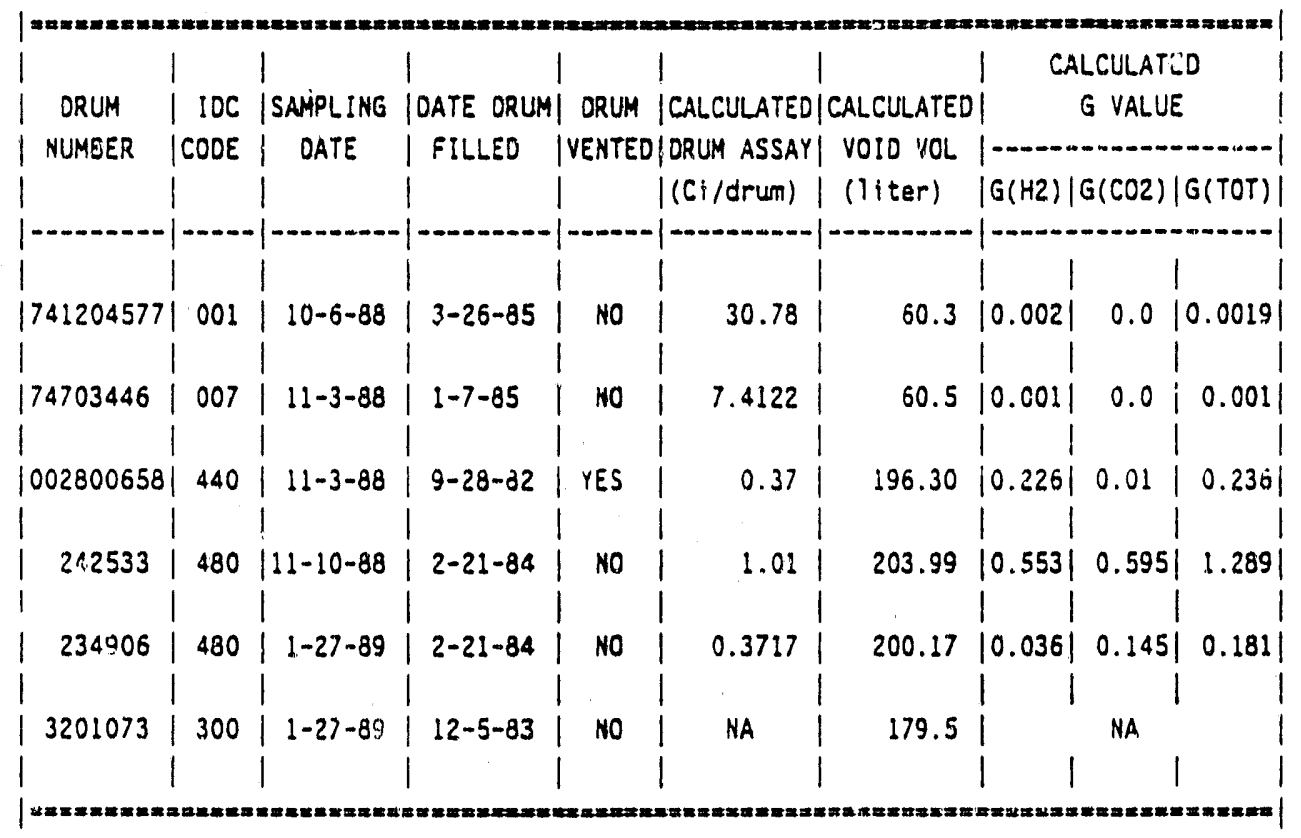

Error can also the introduced into the $G$ value calculation because of analytical and PAN or SGS drum assay error.

\section{CONCLUSIO:S AND RECOMMENDATIONS}

The informatio. in this report covers gas generation by RFP waste, RFP-generated waste has varying concentrations of hydrogen, carbon dioxide, various hydrocarbons, and nitrogen oxides in the headspace and individual waste bags in the six drums sampled. The calculated $\mathrm{G}\left(\mathrm{H}_{2}\right)$ and $G$ (Total) values for the six drums did not exceed any bounding $G$ value. The $G$ (Total) for inorganic solidified sludge ranged from 0.001 to 0.002 . The $\mathrm{G}\left(\mathrm{H}_{2}\right)$ for inorganic solidified sludge ranged from 0.001 to 0.0019 . The $\mathrm{G}$ (Total) for metal, glass, and graphite waste drums ranged from 0.181 to 1.289. The $\mathrm{G}\left(\mathrm{H}_{2}\right)$ for waste bag drums ranged from 0.036 to 0.553 . The $G$ values for inorganic solidified sludge compare favorably to previously reported values. ${ }^{2}$

Possible assumptions that could introduce some error into the $G$ value calculation are:
- $\quad$ All gases remained inside a non-filtered sealed drum with a semi-permeable gasket.

- Gas composition remain the same from the day the drum was ciosed until sampled.

- Individual waste bags were accumulating in the drum before closing.

- All the radiologic decay on the waste inside individual waste bags contacted the plastic material. ${ }^{5}$

\section{REFERENCES}

1. T. L. McFeeters, Hydrogen Permeability Coefficient Determinations for Used Waste Drum Liners, RFP-4377, Rockwcll International, Rocky Flats Plant, Golden, CO, October 1989.

2. D. K. Roggenthen, T. L. McFeeters, and R. G. Nieweg, Waste Drum Gas Gerieration Sampling Program at Rocky Flats, RFP4311, Rockwell Intemational, Rocky Flats Plant, Golden. CO (to be published). 
RFP-4383

3. Safety Analysis Report for the TRUPAC7'-II Shipping Package Docket Number 71-9218, Appendix 3.6.9 - Gas Release Assessment, Nuclear Packaging, Inc., Seattle, WA, February 1989.

4. Safety Analysis Report for the TRUPACT-II Shipping Package Docket Number 71-9218, Appendix 3.6.7 - Effective G Values for
TRUPACT-II Waste Forms, Nuclear Packaging, Inc., Seattle, WA, Fcbruary 1989.

5. Safety Analysis Report for the TRUPACT-II Shipping Package Docket Number 71-9218, Appendix 3.6.8 - Radiolytic G Values for Waste Materials, Nuclear Packaging, Inc., Seattle, WA, February 1989. 

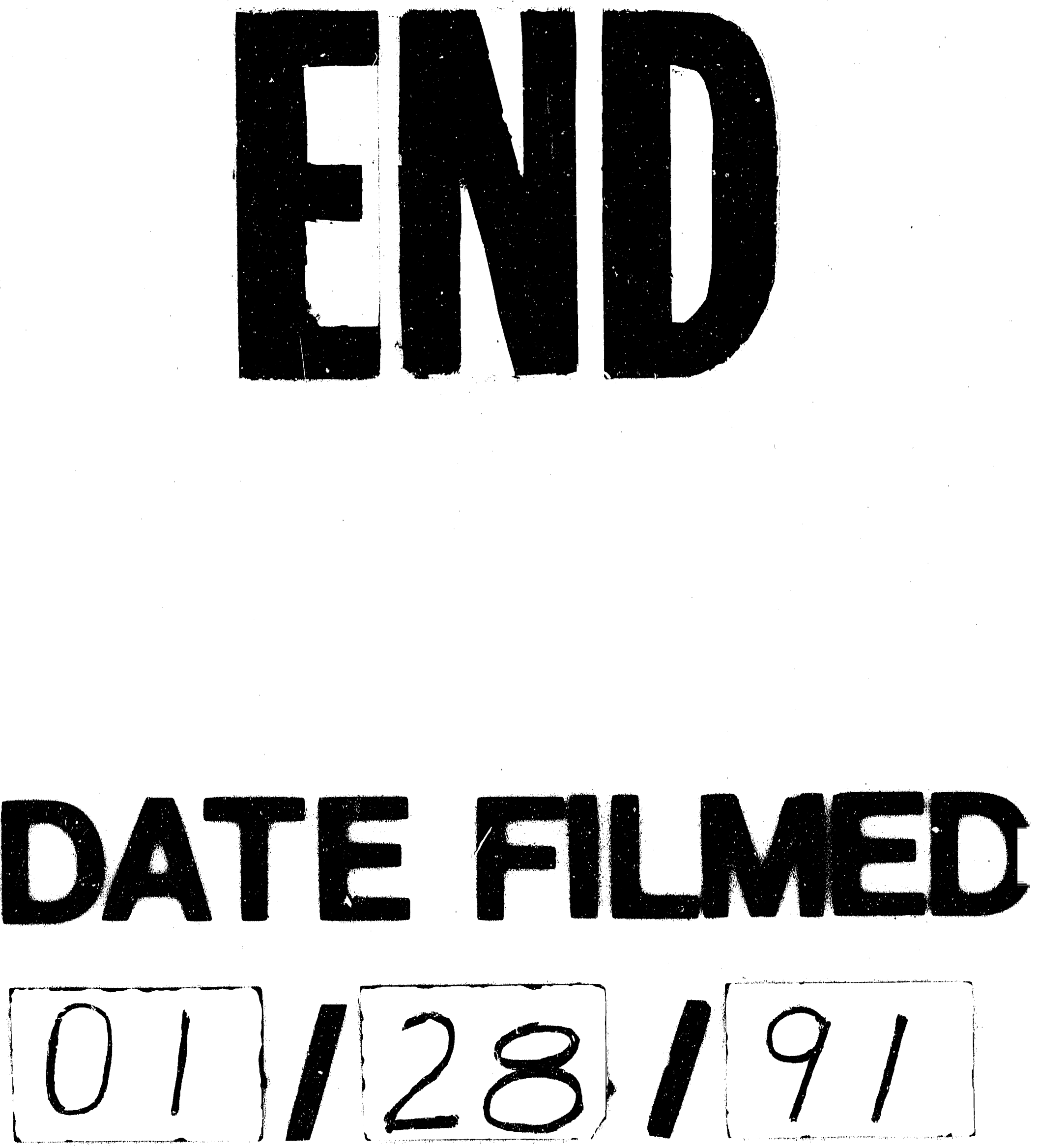
